\title{
Research on the Human-Oriented Ideology and Basis Points of Legal Institution about Peng Zhen's Legislative Thinking
}

\author{
Lv Jingwei \\ Law school, Shanxi University of Finance and Economics, Taiyuan, 030006, China
}

Keywords: Peng Zhen; Legislative Thoughts; Human-Oriented Ideology; Basis Point of Legal Institution

\begin{abstract}
Peng Zhen is the main founder of legal system in China. Based on the social reality of China and used the experience of domestic and foreign legal system, he put forward a series of democratic legislative views, and formed his unique democratic legislative ideas. This paper firstly combs Peng Zhen's exploration of the construction of legal system in our country. Then it systematically discusses the legislative thought connotation of Peng Zhen. At last, it sums up the human-oriented ideology and basis points of legal institution in the process of ruling country by law in our country. The fourth plenary session of the 18th Communist Party of China (CPC) Central Committee announced "comprehensively advancing the rule of law". It is very important theoretical value and practical significance that the legislative thoughts of Peng Zhen and give us some profound enlightenments.
\end{abstract}

\section{Peng Zhen's exploration of the construction of legal system and the formation of his legislative ideas}

Peng Zhen's exploration of the construction of legal system before the foundation of New China.

In 1929, Peng Zhen was arrested by reactionary Kuomintang. In prison, he secretly studied the KMT's Six Codes to fight a battle of wits and courage with the enemy. This experience also was that Peng Zhen systematically contacted law for the first time, and laid the foundation for legislative ideas of Peng Zhen. After released from prison, Peng Zhen arrived in the Shanxi-Chahar-Hebei border region in 1938. He firstly tried the practice that legal system construction of New Democracy in the process of establishing Shanxi-Chahar-Hebeianti-Japanese base-area. This marked his legal thought had taken initial shape. In the base areas, Peng Zhen carried on the practice and exploration in terms of political power construction. According to statistics, the region successively promulgated laws, regulations, guidelines and policies, etc. They were up to 309 pieces. In 1946, Peng Zhen was appointed as Northeast Bureau secretary. He was responsible for creating work of base area in northeast China. According to the CPC central committee's instructions, Peng Zhen successfully completed the "The Outline Land Law of China” writing tasks, and carefully carried out the land allocation work in the anti-Japanese base area. In this period, Peng Zhen's legal system thought was still in the embryonic stage. His expositions about legislation were not systematic and complete. However, through carrying construction of democracy and law, Peng Zhen had accumulated a lot of experience and lessons. All these laid the foundation for his leading Chinese legal system work after the founding of new China.

The Legislation explorations from the founding of New China to the Third Plenary Session of the 11th Central Committee of the Communist.

On October 19, 1949, Peng Zhen attended the third meeting of the Central People's Government Commission. At the meeting, he was appointed as the vice director of Political and legal committee of Government Administration Council. At this point, the legal construction of New China opened a new chapter. In 1954, before the first session of the National People's Congress (NPC), Peng Zhen took part in and presided at formulating the land reform law, marriage law, electoral law, organization law and other important laws and regulations, a total of 506 pieces. These made our legal system take initial shape, and made a good start for Law-based governance. In 1956, Socialism system was basically established in China. On the Eighth National Congress and Eight of 
the first plenary session, Peng Zhen was elected as the member of the Central Committee and the Political Bureau of the Central Committee. From 1949 to 1966, for the sake of our legislation work proceeding smoothly, Peng Zhen constantly thought and gradually formed the legislative ideas with outstanding personal characteristics in the legislation and practice. During the "the Great Cultural Revolution", Peng Zhen was criticized mistakenly. In prison, Peng Zhen did not stop to the exploration of socialist democracy and legal system. Peng Zhen envisaged both positive and negative experiences and lessons since the founding of new China, and conducted more carefully thinking and planning. It was an important period that Peng Zhen legal thoughts gradually became mature.

The Legislation explorations since the Third Plenary Session of the 11th Central Committee.

At the end of 1978, the Third Plenary Session of the 11th Central Committee of the Chinese Communist Party marked our country into the new period of socialist modernization construction. At this meeting, the legal institution was referred to socialist construction strategic position for the first time to know. And as the basic work principle of the central government, it had received the unprecedented attention. After political rehabilitation, Peng Zhen was voted as vice chairman of the NPC Standing Committee, and concurrently held the position of director of the Law Commission of NPC Standing Committee in June 1979. Peng Zhen was appointed as the secretary of The central committee of political science and law in1980. In June 1983, he was voted as the chairman of six sessions of the National People's Congress standing committee. He retired from the party and state leadership positions in 1988, died in 1997. In this period, Peng Zhen made outstanding contributions to the socialist legal system construction. He exerted his utmost effort, worked day and night, and once created a myth that in only more than three months time to formulate seven important draft laws.

\section{The Summary of Peng Zhen Legislative Achievements and Contributions}

Since 1979, under the leadership of Peng Zhen, our country's laws work process was accelerated. The important laws successively formulated were in the following: seven draft laws passed in 1979; "Marriage law" in 1980; the "Civil Procedure Law” (draft) in 1981; the "Constitution Law” revised draft in 1982; the national "General Principles of Civil Law" (draft) in 1985; some economic laws, etc. Peng Zhen's legal system construction theory is rich and precious. It also is the important guidelines that we should follow in the process of governing the country according to laws. It provides a foundation for China's legal system construction, and is an important part of socialist modernization construction.

Attaching great importance to the legislative system reform. By modifying the constitution and formulate relevant laws to settle it. While formulated laws, Peng Zhen attached great importance to the reform of the legislative system. Finally, the legal system was formed that on the basis of the constitution, and laws as the backbone, including administrative regulations, local decrees , administrative and local rules, autonomous decree and special decree of national autonomous areas. At the same time, he also made rules on the problems of authorized legislation and legal interpretation.

Understanding the relationship between Party and laws. When presided over the 1982s Constitution drafting, Peng Zhen proposed that the constitution is the supreme law; the party's activities must be within the scope of the constitution; no organization or individual was in the privilege of transcending the constitution, etc. So, many problems were solved. The key problem on our party and country socialist democracy and legal system had a safeguard. "The communist party of China must abide by the constitution" explicitly wrote in the constitution, Peng Zhen had made positive efforts and historical contribution.

Elaborating the relationship between policy and law. After the founding of new China, Peng Zhen put forward that "During the revolutionary war, the party's policy is the assurance of revolution. The People's Republic of China, is different with previous situation. We cannot live without the rule of law! Chinese legislation, should be a process that a transition from policy guidance to make laws. 
Advocating the legislation principle that "everyone is equal before the law". The first constitution of the People's Republic of China was issued in 1954. And the legal principle of equality was solemnly written inside. Peng Zhen equality ideology is the great achievement of Chinese new culture movement.

\section{The spiritual connotation of Peng Zhen legislative thoughts}

The source on his legislative thoughts.

In one and a half centuries development process of Marxism, There were a series of important ideas and theories being formed. They constituted the glorious prospect of Marxism history. The common points of these important thoughts and theories were that they could solve some major practical problems and guide people to know and transform the world. These theories come from practice. That is, the continuous development of the theory is rooted the further development of practice; And these theoretical innovations based on the practice, are also the forerunner of the development of society. Marxism-Leninism and MAO Zedong thought are the theory source of Peng Zhen legislative thoughts. They are the important component of the Marxism legal theories with Chinese- characteristics, and guide us better to carry out this big project of the rule of law.

Legislation should base on the reality of China to serve our country's economic construction and social development.

Peng Zhen greatly enriched and developed the theory of our country's legislation. Peng Zhen, for example, put forward that seeking truth from facts and suiting the reality of China and national conditions, are not only the starting point of our country legislative work, but also the destination of checking out the result of the inspection legislation is or not scientific and correct; Moreover, the local legislation should start from their own actual situations. After the Third Plenary Session of the Eleventh Central Committee, Peng Zhen emphasized the economic legislation must be as the focus of the legislative work and be on the Party's principles and policies as basis, to adapt to the needs of the reform and opening up.

Legislation should draw lessons from beneficial part of the ancient and modern, Chinese and foreign to perfect the system of democratic centralism, people-oriented.

Peng Zhen emphasized that we should absorb the good experience from our ancient and modern, Chinese and foreign legislation thoughts, which belong to the human common spiritual wealth. We must inherit, absorb and draw lessons from them selectively and critically. Legislation should be geared to the needs of the people, for the people. Legislation also should promote democracy and put heads together. In the work of leading our country legislation, Peng Zhen repeatedly emphasized an important point that: "Legislation should consider peasants, workers... Legislators need to have the farmers, workers, even billion people in their brains, face them, and in order to them.”

Giving full play to the positivity both Central and Regional Government to legislation.

Before 1979, due to the social and historical reasons, our country carried out centralism. There is no legislative power of the place. After the Third plenary Session of the 11th Central Committee, Peng Zhen advocated to expand the powers and authorities of office of NPC Standing Committee and to strengthen its organization in the 1982 constitutional amendment draft report. Peng Zhen stressed that in our country, as the only solution to the problem, the basic law obviously can't stipulate too specific. Otherwise it will be difficult to adapt to the nationwide. For the need of adjusting measures to local conditions to solve the problem, after a law enacted, legislators often need to formulate detailed rules for the implementation. The State Council is responsible for the nationwide implementation, while the National People's Congress and NPC Standing Committee of Provinces, autonomous regions and municipalities are responsible for the formulation of the local conditions. These measures are major reform of China's legislative system. it fully aroused the enthusiasm both central and local governments, developed and perfected the legislative system of our country. It is Peng Zhen another outstanding contribution to our country legislative work. 


\section{The enlightenments on the rule of law construction in the new period in our country}

The rule of law in our country should more sufficiently embody people-oriented ideas.

We should preserve the citizen's rights according to the Constitution and laws. On the one hand, some laws and regulations must be published as soon as possible. We must scientifically set the legislative authority, clearly govern responsibilities of all agencies and departments and make them detailed and specific as far as possible. On the other hand, some relevant laws and regulations to punish corruption should be published as soon as possible.

The rule by law not only should be started from the local practice, but also transplanted foreign outstanding legal results.

Due to some historical reasons in China, the process of our legal system is short. And the rule of law civilization degree is not high. In the economic globalization time, the construction of the rule of law is not any single country's theme. We should not only keep our own style, start from the situation of our country, but also draw lessons from foreign civilization achievements.

Correctly handle the relationship between the Chinese Communist Party and the legislation.

When leading the legislative work, the Chinese Communist Party should promote the combination of policy and legislation, and guide legislative practice with the Party's policy. The Chinese Communist Party should strengthen the work of investigation and study, pay attention to the practice of democracy and legality in our country, and review Peng Zhen's thoughts on strengthening investigation and research the practical situations. It gives us an important enlightenment that we must apply the empirical methods to analyze the current actual situation to build China's legislation.

\section{Conclusion}

Peng zhen made outstanding contributions to the socialist rule of law in our country. In practice, he combined law with all kinds of situation, took a broad and long-term view and took legislative question to a certain height. Peng Zhen's thought to the problems of the legal work of our country has very important guiding function and realistic significance. The study of his legislative thoughts, should also be more closely combined with the big background of the current development of our country, deeply discuss that how to inherit and develop Peng Zhen's thoughts of rule by law under the new situation and complete the related subjects about improving and perfecting the socialist legal system in our country.

\section{References}

[1]A Chronicle of Peng Zhen’s Life (Volume II)[M]. Central Party Literature Press, 2012.

[2] Peng Zhen. Discuss on the Socialist Democracy and Legal System Construction in New Era [M]. Central Party Literature Press, 1989.

[3]Zhang Yanxi. Study on Legislative Explorations and Contributions of Peng Zhen in New Era [D]. Tianjin Normal University, 2014. 05.

[4]Guo Fuyou. Peng Zhen's Legal Thoughts and Its Contemporary Enlightenments[D]. Hunan University of Science and Technology, 2011.04

[5]Zhang Dongyang. Research on Ruling-By-Law Thought of Peng Zhen[D]. Minnan Normal University, 2014,06.

[6]Liu Guoli. Learning Peng Zhen Thought of "Everyone Is Equal Before the Law”. [J]. Research on Mao Zedong Thought, 2012, 01.

[7]Zhu Liyu, Peng Jun. Peng Zhen and the Construction of Democracy and Law of New China-- A Summary on the Research of Peng Zhen Democratic and Legal Ideology $\quad[\mathrm{J}]$. Journal Of Political Science And Law, 2013, 02. 